\title{
原著論文
}

全部床義歯装着者における筋電図による咬合力算出法の簡易化への検討

川崎輝

\section{A Study on Simplification of the Calculations of the Biting Forces Using Integrated Electromyogram in Complete Denture Wearers}

\author{
Teru Kawasaki
}

\section{歯科補綴学的意義}

全部床義歯の機能を評価するために，咬みしめ時の動的咬合力を咀嘶筋筋電図から推定する方法について研究を 行ってきた，本研究では咬合力算出法の簡易化を目的に，すべての全部床義歯装着者を代表する回帰式を求め, 積 分筋電図のみから推定咬合力を算出することが可能か否かを検討した．その結果，全代表式よりも誤差が少ない積 分值別代表式を用いることにより，臨床応用が可能と考えられた。

\section{抄 録}

目的：咀嚼筋筋電図から推定咬合力を算出するシステムにおいて, 患者ならびに術者の負担軽減と測定 精度の向上を目的として咬合力算出法の簡易化を試みた。

方法：経過良好な全部床義歯装着者 49 名を被験者として, すべての被験者を代表する回㷌式（全代表 式）と被験者の筋電図積分值別にクラス分けした回帰式（積分值別代表式）を求め, それぞれ推定咬合 力值の誤差を検討した. 次に, 回帰式の係数 $\beta$ に関係する因子を検索するため, 下頡義歯床面積など の諸因子との相関を検討した。

結果：全代表式から算出した推定咬合力値は，実測值に対し $32 \%$ の誤差を有した。積分値別代表式で は筋電図積分值の最大值が $6.0 \mu \mathrm{V} \cdot \mathrm{s}$ 末満の被験者で実測值に対し誤差は $19 \%, 6.0 \mu \mathrm{V} \cdot \mathrm{s}$ 以上の被験 者で $25 \%$ であることが示された. 回帰式の係数 $\beta$ との相関は, 高い順に下顎臼歯部顎堤の断面積, 筋

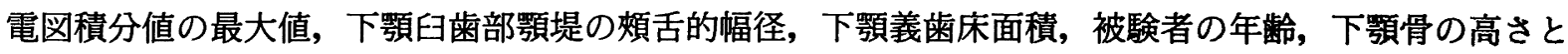
なった.

結論：積分值別代表式を用いることにより咬合力算出法の簡易化が可能と考えられたが, 回㷌式の係数 $\beta$ に関係する因子を考慮して代表式を求めることにより，さらに精度が向上する可能性が示唆された.

$$
\text { 和文キーワード }
$$

全部床義歯, 機能評価, 咬合力, 筋電図積分値

鶴見大学歯学部歯科補緅学第一講座（指導：細井紀雄教授）

The First Department of Prosthetic Dentistry, Tsurumi University School of Dental Medicine (Director: Prof. Toshio Hosoi)

受付 : 2000 年 8 月 9 日/受理 : 2000 年 11 月 13 日

Received on August 9, 2000/Accepted on November 13, 2000 


\section{I. 緒 言}

補綴装置の客観的機能評価法として行われる咬合力 測定では，患者の口腔内や使用する義歯に咬合力測定 装置を介在させる必要があることから，咬合高径が挙 上されたり，適正な下顎位で咬合力を測定することが 困難であった。さらに，装置の介在により咬合接触が 失われるなどの問題もあった。近年, 薄膜状の圧力素 子を用いた $\mathrm{T}$-scan system ${ }^{1)}$ ，感圧シート ${ }^{2}$ などが開 発され，広く臨床に応用されるようになった。しか し，センサーの感度が高く，逆に誤差を生じるという 問題もあった ${ }^{3)}$. また,これらの装置により算出され る咬合力は静的な咬合力であり, 補綴装置の評価を行 ううえでは，機能時の動的な咬合力を把握し，これを 観察することも必要である，そこで当教室では，患者 の使用する義歯と同一の咬合高径および下顎位で患者 の動的咬合力を測定するシステムを開発し，有歯顎者 および無歯顎者の筋電図から咬合力の算出を行ってき た ${ }^{4 \sim 7}$. これは，等尺性収縮時における咀嚼筋の筋活 動量と咬合力の相関が高いという報告8をもとにして なされたものである．本システムではまず，被験者の 複製義歯にロードセルを組み込んだ咬合力測定用義歯 を製作し，咀嚼筋筋電図と咬合力の同時測定を行い, 両者の回帰式を求める. 次に, 被験者が使用する義歯 で筋電図のみを測定し，回帰式に筋電図積分值を代入 して，推定咬合力値を算出する．ここで，すべての患 者に対して，推定咬合力を算出する代表回帰式を導く ことができれば，咬合力測定用義歯の製作ならびに咬 合力と咀嚼筋筋電図の同時測定の過程を省略し, 推定 咬合力を算出することが可能となる.

本研究は咬合力算出法の簡易化を目的に，多くの被 験者から得た筋活動量と咬合力の散布図をもとに，す べての被験者を代表する回帰式が求められるかについ て検討した。さらに，これを全代表式として被験者の 推定咬合力值を算出し, 咬合力の実測値との誤差につ いて検討を加えた．次に，筋電図積分值別による被験 者のクラス分けを試み，各クラスの被験者の散布図か ら回帰式を求め, これを積分值別代表式として推定咬 合力值を算出し, 咬合力の実測値との誤差を検討し た.また，筋電図積分値以外の因子について回帰式の 係数との関係を追求し，本システムにおける測定精度
の向上の方策を検索した.

\section{II. 研究方法}

\section{1. 被験者}

被験者は本学歯学部附属病院に来院した無歯顎患者 で, 上下顎全部床義歯を製作後, 義歯調整を終了した 49 名である。被験者の内訳は男性 22 名, 女性 27 名, 平均年齢 $73.1 \pm 6.6$ 歳で, 無歯顎のほか, 顎口腔系に 異常を認めない者である.

\section{2. 咀嚼筋筋電図および咬合力の測定}

1）咀嚼筋筋電図，咬合力の同時測定

咬合力測定用義歯は石川占の方法に準じて製作した (図 1). 被験者をシールドルーム内の椅子に座らせ, 被験者のフランクフルト平面が床と平行となるように 頭部を位置づけた。咬みしめ条件として，桝尾》の報 告を参考に 5 秒間で 5 回の速さで開閉運動を行わせ, 閉口時に疲労感を覚えない程度の最大レベルで咬みし めを指示した。被験筋は左右側咬筋中央下部および側 頭筋前部の計 4 筋とした。測定に先立ち, 咬合力測定 用義歯を口腔内に装着し，2 分間ロードセルの温度補 償を行い，筋電計とストレインアンプの較正電圧を補 正した後，安静時筋活動電位を記録した。

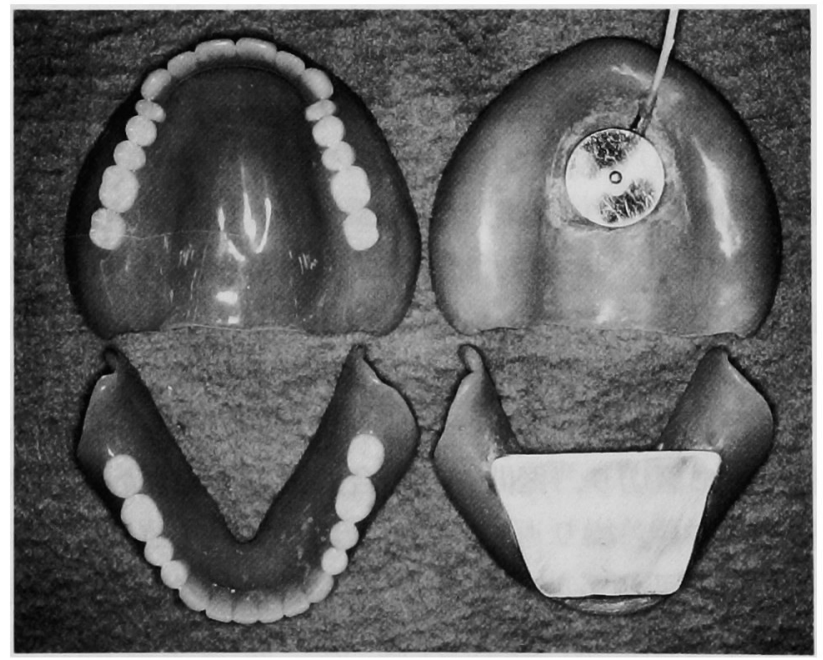

Subject's denture

Experiment denture for measuring the bite forces

図 1 Subject's denture and experiment denture for measuring the bite forces 被験者の使用義歯と咬合力測定用義歯の一例 
(1)

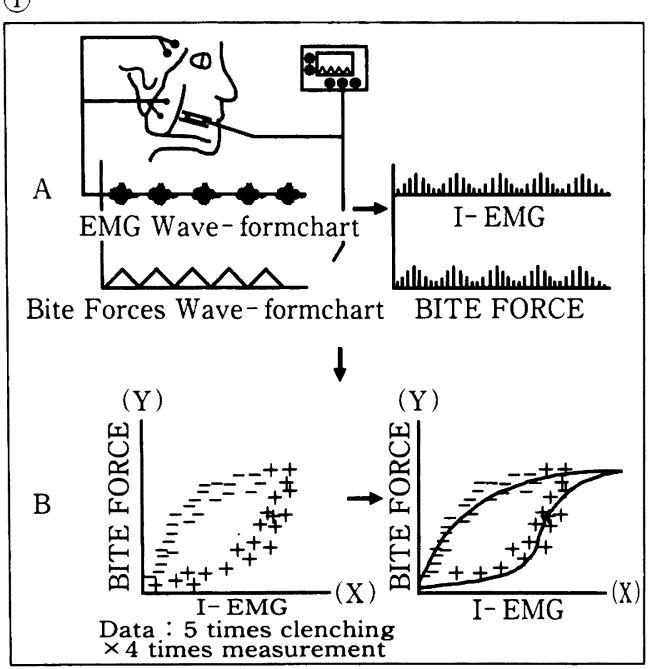

(2)

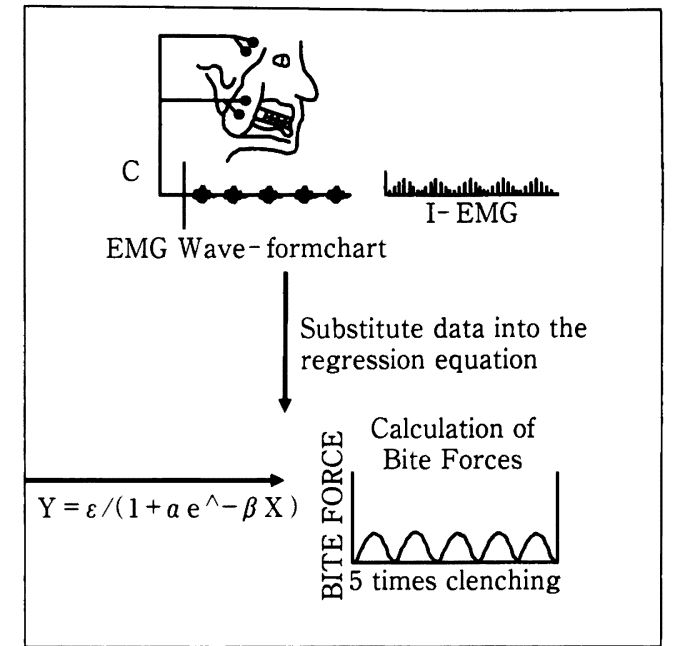

図 2 Flow chart of measurement of bite forces during clenching

A : 4 times synchronous measurement of EMG of the 4 muscles and bite forces for calculate I-EMG and bite foces

B : Discribe the scattering figure to relation between I-EMG and bite forces, conform regression equation to increase and decrease data of bite forces

C : Substitute EMG data to gain using denture of subjects into the regression equation, and calculate of the bite forces

咬合力測定のフローチャート

$\mathrm{A}: 4$ 筋の筋電図および咬合力の同時測定を 4 回繰り返し, 積分值と区間平均咬合力值を算出する

B : 両者の関係を表す散布図を描き, 咬合力増加時ならびに減少時のデータに回㷌曲線を適合する

$\mathrm{C}$ ：被験者の使用義歯により得られた筋電図データを回㷌式に代入し，推定咬合力値を算出する

筋電図と咬合力の同時測定は咬合力測定用義歯にて 4 回, 筋電図の測定は被験者の使用義歯にて 4 回それ ぞれ行った.すべての測定には当教室で開発したシス テム ${ }^{4,9)}$ を用いた。

2）筋電図積分値および区間平均咬合力值の算出

図 2 の (1)に, 本システムのフローチャートを示す. 筋電図と咬合力の同時測定により得られたデータのう ち, 筋電図データはデジタル化し, 整流後, 安静時筋 活動電位より大きいデー夕を取り出し， 0.05 秒間隔 に区切り，各区間ごとに筋電図積分值を求めた ${ }^{4)}$.

また，筋電図積分值と同様に咬合力データを 0.05 秒間隔に区切り，区間平均咬合力值を算出した。各被 験者につき, 繰り返し 4 回測定分のデー夕（5 回咬み しめ $\times 4$ 回測定）を, 縦軸に区間平均咬合力値 $(\mathrm{kgf})$, 横軸に筋電図積分值 $(\mu \mathrm{V} \cdot \mathrm{s})$ とするグラフ にすべてプロットし，散布図として表した。散布図上 のデータは咬合力増加時（図の十印）のものと減少時 (図の一印) のものに分け, 増加時のデータにロジス ティック曲線を, 減少時のデータに修正指数曲線を適
合し，それぞれ回帰式を求めた7).

\section{3. 推定咬合力値の算出}

1) 被験者個々の推定咬合力値の算出

被験者に義歯を装着させ, 図 2 の (2) に示すように, 先の咬みしめ条件で咀嚼筋筋電図のみを測定し, 得ら れた筋電図データをあらかじめ算出しておいた被験者 個々の回帰式に代入し, 推定咬合力値を算出した.

2）代表式による推定咬合力值の算出

被験者 49 名の散布図を 1 つのグラフ上に重ね書き （5 回咬みしめ $\times 4$ 回測定 $\times 49$ 名）し，これに回帰曲 線を適合して全代表式を求めた。 49 名の被験者にお ける義歯装着時の筋電図データをそれぞれ全代表式に 代入し, 各被験者について推定咬合力值を算出した。

積分值別代表式については, 筋電図積分値 (IEMG）の最大值を指標として被験者のクラス分けを 行った。筋電図積分值の最大值 $(\mathrm{MAX} \cdot \mathrm{I}-\mathrm{EMG})$ を, $2.0 \mu \mathrm{V} \cdot \mathrm{s}$ 以上 $4.0 \mu \mathrm{V} \cdot \mathrm{s}$ 末満をクラス $\mathrm{A}, 4.0$ $\mu \mathrm{V} \cdot \mathrm{s}$ 以上 $6.0 \mu \mathrm{V} \cdot \mathrm{s}$ 末満をクラス $\mathrm{B}, 6.0 \mu \mathrm{V} \cdot \mathrm{s}$ 以上 


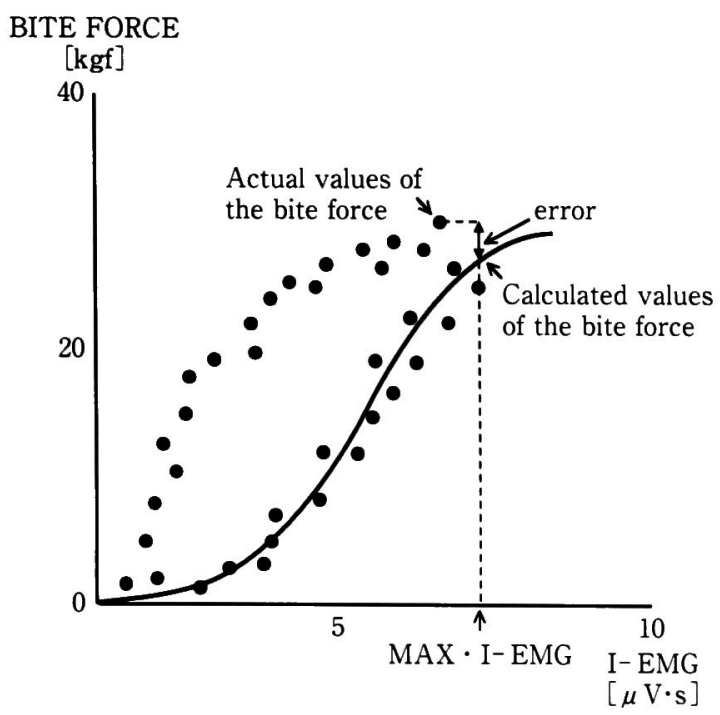

図 3 Calculation of the error of the calculated and actual values of the bite force 咬合力の実測值に対する推定咬合力値の誤差 の算出法

をクラス C とし，各クラスにあてはまる被験者の散 布図を重ね書きし，代表式を算出した。

\section{4. 推定咬合力値の誤差の算出}

図 3 に，誤差の算出法を示す。 5 回の咬みしめを繰 り返し 4 回測定した計 20 データの平均值から推定咬 合力值と実測した咬合力值の差を求め, 誤差を算出し 百分率で表した。

\section{5. 回帰式の係数に影響する因子}

回帰式の係数に影響する因子として，筋電図積分值 の最大值，年齢，下顎骨の高さ，下顎義歯床面積，下 顎臼歯部顎堤の頓舌的幅径，下顎臼歯部顎堤の断面積 の 6 項目を取り上げた。これらの各因子と回帰式の係 数との関係を検討するため, 各因子ごとに一次回帰に よる分析を行った。各因子における計測值と回帰式の 係数との関係は，相関係数，決定係数および分散分析 を用い, 統計処理を行った。

1）下顎骨の高さの測定

下顎骨の高さはパノラマX線写真より計測した。下 䪽骨の高さの測定は，オトガイ孔下緑から下顎骨上緑 までの距離を $\mathrm{a}$ ，オトガイ孔下縁から下顎骨下縁まで の距離を b とし, 下顎骨の高さを $\mathrm{a} / \mathrm{b}$ の比率で表し た ${ }^{10,11)}$ 。各被験者において左右側それぞれ 3 回計測

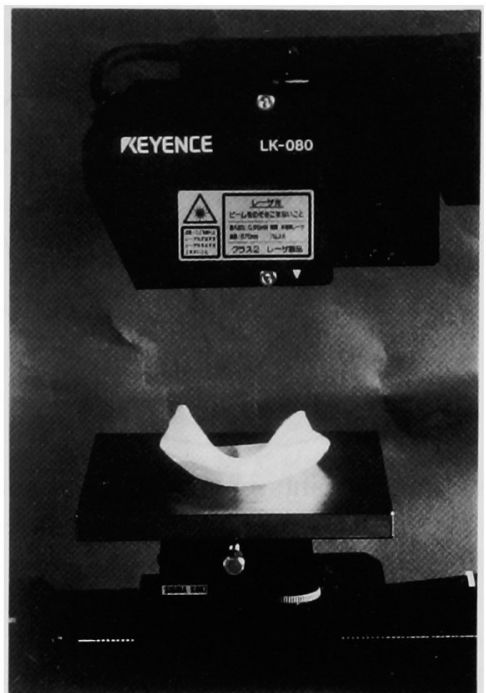

図 4 Measurement of the lower denture base form by CCD Laser LK-2100 and a high speed 3-D EMS 98 AD-3 D $100 \mathrm{XY}$

CCD レーザー測定器 LK-2100 と高速三次元形状測 定システム EMS 98 AD-3 D 100 XY による下顎義 歯基底面の計測

し, 合計 6 回の計測データの平均値を各被験者の下顎 骨の高さの比率とした。

2）下顎義歯床面積，下顎臼歯部顎堤の煩舌的幅 径, 下顎臼歯部顎堤の断面積の測定

計測 は CCD レーザ測定器 (LK-2100, KEYEN$\mathrm{CE}$ ，東京）および高速三次元形状測定システム (EMS 98 AD-3 D 100 XY, シグマ光機, 東京）を用 いて行った（図 4).下顎義歯の基底面をアルジネー 卜印象材で印象採得後, 硬質石膏にて計測用模型を製 作しこれを測定対象とした。

下顎義歯床面積は義歯床辺縁の最深部ならびに後縁 をマークし，CRT 画面上で $1.0 \mathrm{~mm}$ ピッチでプロッ トすることにより設定した. 各被験者において 3 回計 測し，平均值を各被験者の下顎義歯床面積とした。

下顎臼歯部顎堤の煩舌的幅径の測定方法を, 図 5 に 示す。各被験者において左右側それぞれ 3 回計測した データを左右側で平均し, 左側ならびに右側の和を下 顎臼歯部顎堤の煩舌的幅径として求めた。

下顎臼歯部顎堤の断面積は, 下顎臼歯部顎堤の煩舌 的幅径の計測点を含み，咬合平面に対して垂直な面と した。断面積は，煩側ならびに舌側の義歯床縁を基準 として咬合面方向をプラス，下顎骨下縁方向をマイナ スとして表した．各被験者において下顎臼歯部顎堤の 


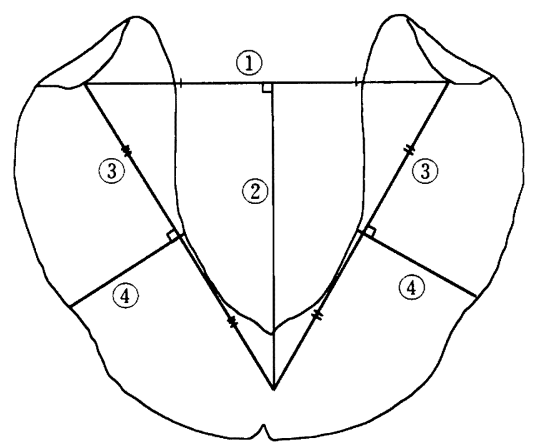

図 5 Measurement points on the buccolingual width of the alveolar ridge of a lower posterior tooth region

(1): The lines that links the middle point left retromolar pad with the middle point of light retromolar pad

(2): The perpendicular bisector of (1) to alveolar ridge processes of anterior

(3): The line that links the terminus of (2) with the middle point of left and light retromolar pad

(4): The perpendicular bisector of (3), and the lines that links denture floor rims of cheek with denture floor rims of lingua. This is buccolingual width of the alveolar ridge in the lower posterior tooth region

下顎臼歯部顎堤の煩舌的幅径の測定部位

(1)：左右側レトロモラーパッドの中点を結ぶ

(2)：(1)の中点から前歯部頡堤頂まで垂線を下ろす

(3)：(2)の終点から左右側レトロモラーパッドの中点 を結ぶ

(4)：(3)の中点に垂直になるように義歯床縁までを結 び，これを下顎義歯臼歯部煩舌的幅径とする

頓舌的幅径と同様に，左右側の和として求めた.

\section{III. 研究結果}

1. 被験者個々の回帰式による推定咬合力値の算出

咬合力の実測值と被験者個々の回帰式により算出し た推定咬合力值の結果を，図 6 に示す．実測値に対す る推定咬合力値の誤差は, 平均で $5.9 \%$ であった。

\section{2. 全代表式による推定咬合力値の算出}

全代表式は全被験者の散布図を 1 つのグラフ上に重 ね書きし，回帰曲線を適合させた（図 7)。得られた 全代表式の相関係数は 0.67 , 曲線の係数 $\beta$ は 0.73 を 示した。この全代表式に, 各被験者から得られた筋電 図データを代入し，推定咬合力值を算出した．各被験 者について咬合力の実測值に対する推定咬合力值の誤 差は平均 $32.4 \%$ を示した。

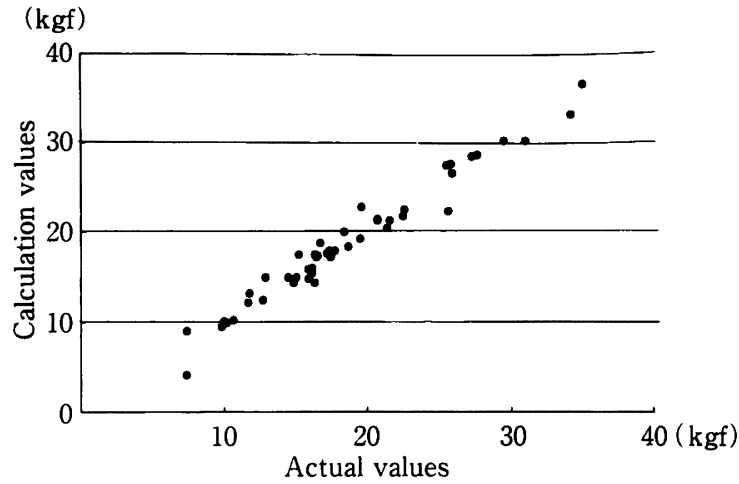

図 6 Results of the calculated maximum values by the formula and the actual maximum values for the bite force in each subject 咬合力の実測值の最大値および被験者個々の 回帰式による推定咬合力値の最大值の結果

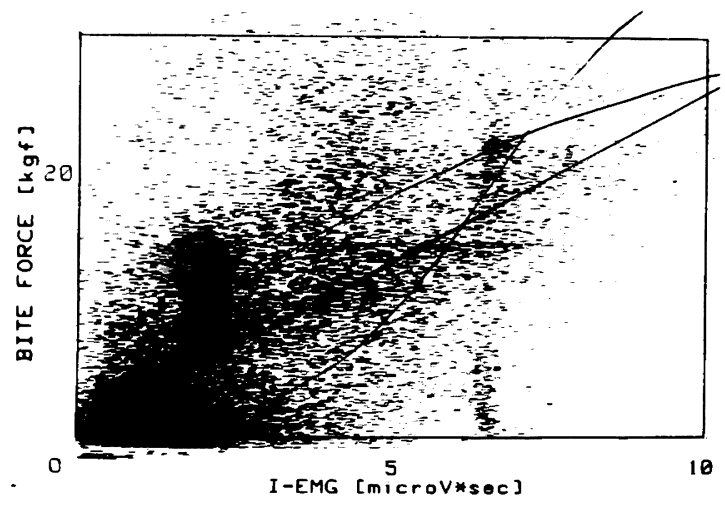

$$
\mathrm{Y}=\frac{37.38}{1+115.8 \mathrm{e}^{\wedge}-0.7339 \mathrm{X}} \quad(\mathrm{r}=0.67)
$$

図 7 The formula in all the subjects which calculated from the data ( 5 times clenching $\times 4$ times measurement $\times 49$ subjects)

すべての被験者のデータ（5回咬みしめ $\times 4$ 回測 定 $\times 49$ 名）から得られた全代表式

\section{3. 積分値別代表式による推定咬合力値の算出} 被験者 49 名の筋電図積分値の最大値の分布を，図 8 に示す．筋電図積分值の最大值がクラス $\mathrm{A}$ の者は 18 名，クラス Bが 18 名，クラス Cが 13 名であった.

クラスごとに被験者の散布図を重ね書きし，代表す る回㷌式を求めた（図 9)。積分值別代表式の相関係 数はクラス $\mathrm{A} て ゙ 0.70$, クラス Bで 0.64 , クラスCで 0.73 であった. 各クラスにおける代表式の係数 $\beta$ は, クラス $\mathrm{A} て ゙ 1.66$, クラス $\mathrm{B} て ゙ 0.93$ ，クラス Cで 0.78 となった。

次に, 積分値別代表式に被験者の筋電図データを代 入し，推定咬合力值を算出した。咬合力の実測值に対 
する推定咬合力值の誤差は,クラス $\mathrm{A} て ゙$ 平均 $17.4 \%$, クラス Bで平均 $18.7 \%$, クラス C で平均 $25.2 \%$ であった。

以上，3つの算出方法における誤差について分散分 析を行った結果，被験者個々の回帰式による算出法と 全代表式による算出法, 積分値別代表式による算出法 と全代表式による算出法の間にそれぞれ有意差が認め

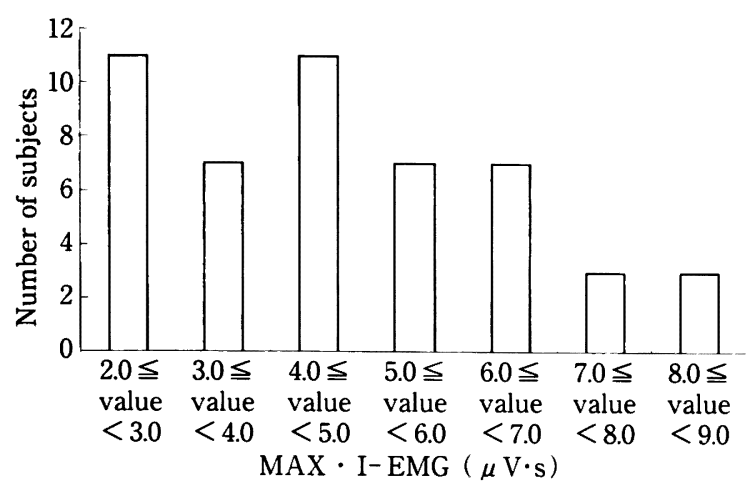

図 8 The distribution of the maximal I-EMG 筋電図積分値の最大値の分布 られた（p<0.05）。また，被験者個々の回帰式によ る算出法と積分値別代表式による算出法の間にはクラ ス Cを除いて有意差は認められなかった（ $\mathrm{p}>0.05 ）$ (表 1).

\section{4. 回帰式の係数に影響する因子}

回帰式の係数 $\beta$ に影響する各因子について，筋電 図積分値の最大値, 年齢, 下顎骨の高さ，下顎義歯床 面積, 下顎臼歯部顎堤の煩舌的幅径, 下顎臼歯部顎堤 の断面積の測定結果を, 表 2 に示す.

回帰式の係数 $\beta$ とこれに影響を与える因子の相関 係数, 決定係数および $\mathrm{F}$ 值を図 10 に示す。相関係数 の高い因子は，下顎臼歯部顎堤の断面積および下顎臼 歯部顎堤の煩舌的幅径であった。

\section{IV. 考察}

\section{1. 研究目的について}

全部床義歯装着者の咀嚼機能の回復程度を客観的に
Class A

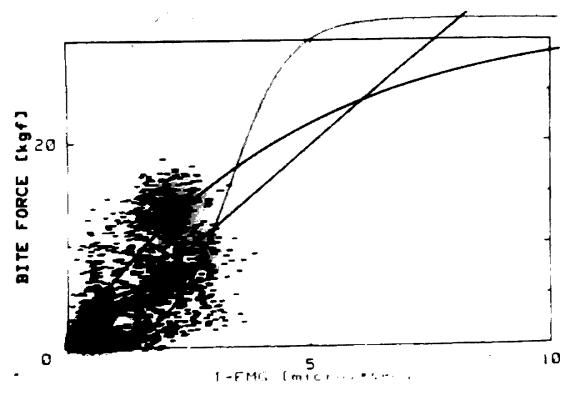

$$
\mathrm{Y}=\frac{32.08}{1+262.7 \mathrm{e}^{\wedge}-1.659 \mathrm{X}} \quad \begin{array}{r}
\mathrm{r}=0.70) \\
(\mathrm{n}=18)
\end{array}
$$

Class B

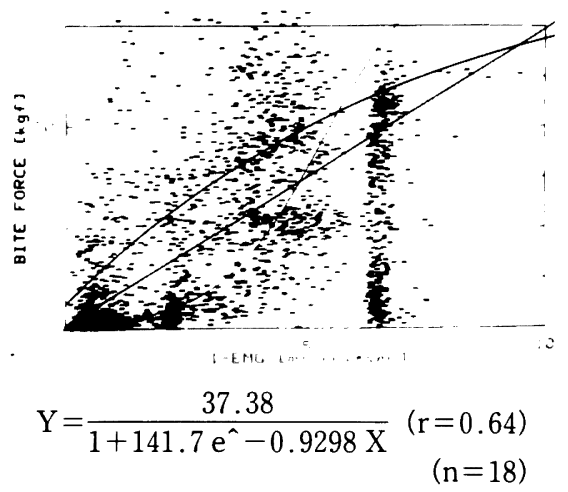

Class C

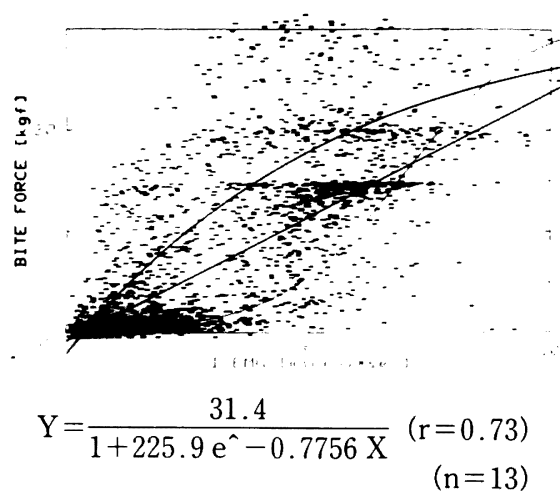

図 9 The formula of respective I-EMG which calculated from the data (5 times clenching $\times 4$ times measurement $\times$ number of each class subjects)

各クラスの被験者のデータ（5 回咬みしめ $\times 4$ 回測定 $\times$ 各クラスの被験者数）から得られた積分值別代表式

表 1 Mean error for each calculations 各算出法における誤差の平均値

\begin{tabular}{|c|c|c|c|}
\hline & Mean error $(\%)$ & & \\
\hline Calculated from the formula in each subject & $5.9 \pm 7.4$ & & \\
\hline \multicolumn{4}{|l|}{ Calculated from the representative formula of respective I-EMG } \\
\hline 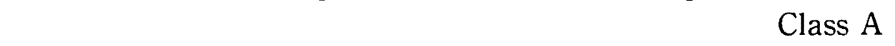 & $17.4 \pm 11.57$ & * & \\
\hline Class B & $18.7 \pm 16.9-$ & & $*$ \\
\hline Class C & $25.2 \pm 20.4 f^{*}$ & & \\
\hline Calculated from the representative formula in all the subjects & $32.4 \pm 29.4]$ & & \\
\hline
\end{tabular}

$*$ : significant difference $(\mathrm{p}<0.05)$ 
表 2 Result of measurement of the influence factor the regression curve 回帰式に影響を及ぽす因子の測定結果

\begin{tabular}{lccc}
\hline \multicolumn{1}{c}{ Every measurement item } & Mean $(\mathrm{SD})$ & Minimum & Maximum \\
\hline MAX $\cdot \mathrm{I}-\mathrm{EMG}(\mu \mathrm{V} \cdot \mathrm{s})$ & $4.76(1.79)$ & 2.07 & 8.91 \\
Age (years) & $73.1(7.3)$ & 57.0 & 85.0 \\
Mandibular corpus height $($ ratio $)$ & $0.8(0.3)$ & 0.3 & 1.5 \\
Area of lower jaw denture base $\left(\mathrm{mm}^{2}\right)$ & $2,317(935)$ & 1,211 & 4,566 \\
Buccolingual width of the alveolar ridge $(\mathrm{mm})$ & $27.1(6.6)$ & 14.1 & 42.8 \\
Buccolingual cross-sectional area $\left(\mathrm{mm}^{2}\right)$ & $306(1,166)$ & $-3,020$ & 1,598 \\
\hline
\end{tabular}

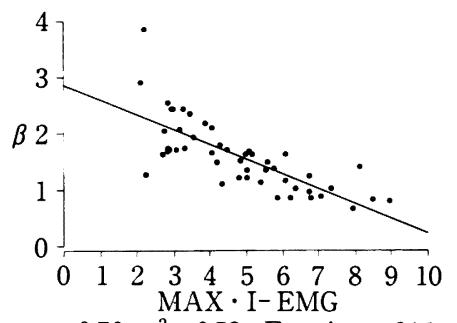

$\mathrm{r}=0.76, \mathrm{r}^{2}=0.58, \mathrm{~F}-$ value $=64.1$

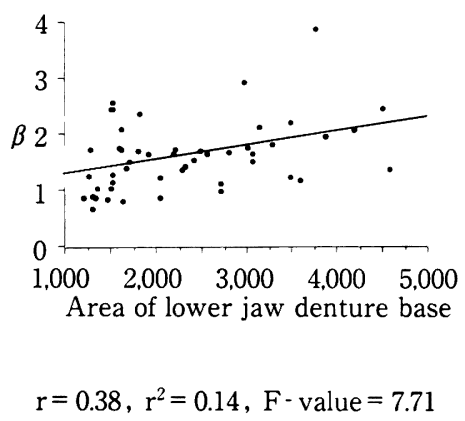

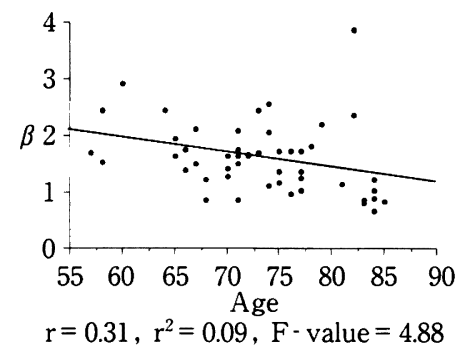

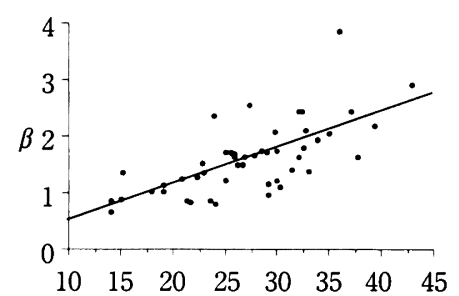

Buccolingual width of the alveolar ridge in the lower posterior tooth region

$\mathrm{r}=0.68, \mathrm{r}^{2}=0.47, \mathrm{~F}-$ value $=41.0$
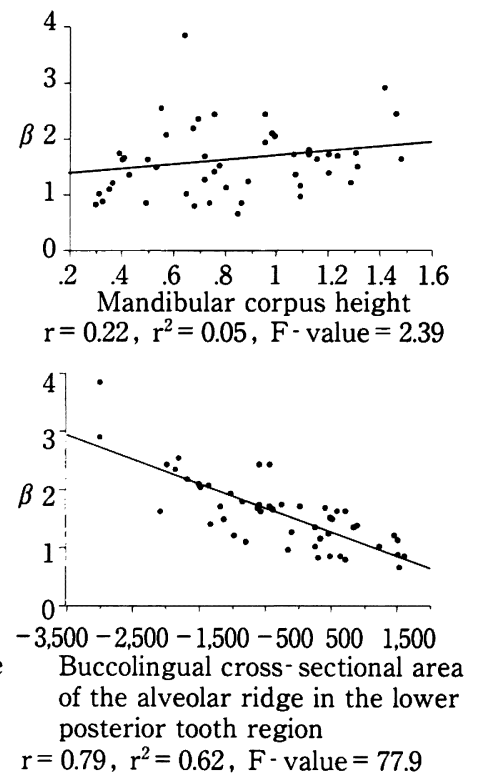

図 10 The relation between influencing factor the regression curve and the coefficient $(\beta)$ 回帰式に影響を及ほす因子と係数 $\beta$ との関係（n=49）

評価する手段として，咬合力は有効な指標である．当 教室では, 従来より筋電図学的手法を用いた咬合力の 算出法を検討してきた。

咀嚼筋筋電図から推定咬合力を算出する方法を臨床 で応用する場合, 患者の来院回数と術者の煩雑な手技 が支障となる，そこで今回, 咬合力と咀嚼筋筋電図積 分値との関係を示す被験者の散布図から代表式を算出 する方法を試みた，すなわち，数多くの全部床義歯装 着者の散布図を集積することにより，それらを代表す る回帰曲線が得られないかと考えた。ささらに，筋電図 積分値を指標として被験者を分類し，回帰式を求め， 測定精度がどの程度向上するかについて検討した。ま た，測定精度向上の面から，回帰式の係数に最も関係 する因子を検索することにより適切な回帰式を選択す ることが可能と考えられた。

\section{2. 研究方法について}

被験者については，上下顎全部床義歯を製作後，経 過良好と判定した患者をランダムに選択した. 全部床 義歯装着者には高齢者が多く, 体力, 筋力の低下が認 められるため ${ }^{12)}$, 測定による精神的ストレスや筋疲 労 ${ }^{13)}$ が咀嚼筋筋電図に影響を及ほすことのないよう, 測定と測定の間に 2 分間の休息を挟んだ.

被験者の男女比は $1: 1.2$ であった。女性の咬合力 発現時の筋活動は, 男性に比べて遅い(4)など, 咬合力 や筋活動の発現能力において性差が影響すると考えら れるが, 咀噮筋の咬合力発現と筋の活動効率に関する 報告はみられず，性差による分類は行わなかった。

本システムでは, 患者の義歯使用時と近似した生理 的条件で咬合力を求めることが前提である．石川 は, 咬合高径の違いによる筋電図積分值と区間平均咬 合力值との関係を検討し, 咬合高径が $\pm 0 \sim+2 \mathrm{~mm}$ 
の範囲であれば筋電図積分値より算出する推定咬合力 值への影響は少ないと述べている。一方，遠藤 ${ }^{15)}$ は咬 合高径の増減が咬合力値および咀嚼筋筋電図に影響す ることを報告している，また，咬合高径を低く設定す

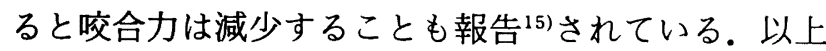
のことから，咬合力測定用義歯は患者の使用する義歯 と同一のとき，はじめて適正な咬合力の算出が可能と なる。

咬合力の作用点を変位させると床下粘膜の局所負担 圧分布は著しく変化することが，定量的に証明されて いる ${ }^{16 ~ 21)}$. 義歯床下粘膜において負担圧を適正に配 分するには，咬合力の作用点を下顎義歯の正中線と左 右第一大臼歯近心辺緑隆線を結ぶ線分との交点付近に 設定することが示されている22). 本研究ではこれらの 報告を参考に，ロードセルを設置した。

被験筋の選択については，左右側咬筋および側頭筋 前部の 4 筋とした。本研究において被験筋の組合せに よる回帰曲線の適合度の違いを，左右側咬筋および側 頭筋の計 4 筋を平均する方法, 左右側咬筋および左右 側側頭筋を平均する方法の 2 通りから検討した。その 結果, 後者に比べ, 4 筋を平均する方法において曲線 の回帰係数が高くなることが示され，同様の検討を 行った寒河江 ${ }^{23}$ の報告と一致した見解が得られた.

咬みしめ条件について，本研究では 5 秒間に 5 回の 速度で, 被験者が痛みを感じない範囲の最大の咬みし めを指示した。平田 ${ }^{6}$ は，5秒間に 1 回の緩やかな咬 みしめでは, 筋電図積分值から算出した推定咬合力値 は実測値にきわめて近似し，咬みしめ周期が速くなる ほど誤差が増加することを示した。これに対し栘尾7 は, 咀嚼リズムに近い 5 秒間に 5 回の周期で同様の研 究を試み, ループ状に分布した散布図上のデータに二 次式を回帰させる方法を考案して, 推定咬合力值の算 出精度の向上を図った. 5 秒間に 5 回の咬みしめは臨 床応用に適した条件と考えられたことから，本研究に おいてもこの条件を採用した。

本システムにおいて咬合力の実測值と推定咬合力值 の誤差が生じる要因は, 最大咬合力発現に先行して最 大筋活動が発現するための夕イムラグ，ならびに散布 図に回帰させる曲線の適合度によると考えられる。実 測値と推定咬合力值の誤差が最も大きくなるのは咬合 力の最小值, 最大值付近あるいは筋電図積分值の最小 值，最大值付近であることが桝尾》によって報告され
ている。これは，ループ状に分布した散布図に適合す る曲線の特徵によると推察される.

回帰式の係数 $\beta$ に影響する因子について, 総筋活 動量を指標とする方法も考えられるが，二次回帰式の 係数と総筋活動量の相関は 0.61 , 筋電図積分值の最 大値との相関は 0.76 であったことから, 本研究では 筋電図積分値の最大値を影響因子とした。

\section{3. 研究結果について}

栘尾》 は, 被験者個々の回帰式による推定咬合力値 は実測值に対し，10\% 以下の誤差を生ずると報告し た. 本研究で被験者個々の回帰式による推定咬合力值 の誤差は $6 \%$ であり, 臨床応用に十分な高い測定精度 を有することが裏付けられた。簡易化を目的とした全 代表式による方法は誤差 $32 \%$ で, 義歯機能の評価は 困難であることが示された。積分值別代表式による方 法では, 筋電図積分値の最大值が $6.0 \mu \mathrm{V} \cdot \mathrm{s}$ 末満の被 験者で誤差は $19 \%, 6.0 \mu \mathrm{V} \cdot \mathrm{s}$ 以上の被験者で誤差は $25 \%$ であった. 筋電図積分值の最大值が $6.0 \mu \mathrm{V} \cdot \mathrm{s}$ 末 満の被験者は 36 名, $6.0 \mu \mathrm{V} \cdot \mathrm{s}$ 以上の被験者は 13 名 であることから, 被験者の約 73\% は誤差 19\% で推定 咬合力の算出が可能であることが示された。

下顎義歯において, 義歯床面積, 臼歯部顎堤の煩舌 的幅径が大きいほど義歯の維持安定にとって有利であ ることは事実である。しかし, 義歯床面積や臼歯部顎 堤の煩舌的幅径が大きくても平坦な顎堤を有する被験 者も存在する.このような症例は顎堤の断面積が小さ いため, 義歯の維持安定や咬合力に対する負担能力か ら考えても不利であり, 義歯装着後の経過が不良にな りやすい.このような理由により, 回帰式の係数 $\beta$ と下顎臼歯部頡堤の断面積の間で相関が高かったもの と推察される. 咬合力や筋活動と被験者の年齢との関 係については知見が報告 ${ }^{24)}$ れているが, 本研究にお いては高い相関は得られなかった。ここで影響因子と して取りあげる場合は，年齢よりも義歯経験年数や無 歯顎の年数を検討する必要があると考えられた。

下顎骨の高さについては, 計測部位をオトガイ孔を 基準としたため，相関が低かったと思われる，下顎臼 歯部顎堤の断面積で相関が高かったことを考慮する と, 咬合力負担域である臼歯部顎堤の高さの定量化に ついて検討する必要があると思われた。

本研究の結果, 積分値別代表式を用いた咬合力算出 
により可及的に誤差を小さくすることができ，これに より，臨床的に十分な精度を保った状態で咬合力算出 の簡易化が可能と考えられた.今後は積分值別代表式 により被験者をクラス分けした後，下顎臼歯部顎堤の 断面積などの因子を加えた代表式を示すことによって さらに誤差を小さくすることが課題である.

\section{V. 結 論}

1. 全代表式から算出した咬合力値は, 臨床に応用 する場合精度上好ましくないと考えられた。

2. 積分値別代表式から算出した咬合力値は，全代 表式から算出した咬合力值よりも精度がよく，臨床応 用が可能と考えられた。

3. 下顎臼歯部顎堤の断面積, 筋電図積分値の最大 值, 下顎臼歯部顎堤の煩舌的幅径は，被験者個々にお ける二次回帰式の係数 $\beta$ と関連が高かった.

稿を終わるに臨み，終始ご懇篤なるご指導とご校閲を賜りま した本学歯学部歯科補経学第一講座細井紀雄教授に深甚なる感 謝の意を捧げます.

また本研究の遂行に際し有益なご助言と惜しみないご支援を いただききました大貫昌理講師，東條敏明博士に敬意を表しま す。さらに，有益なご教示を賜りました椎名順朗講師に深謝い たします。あわせて多大なるご協力，ご理解をいただきました 教室員諸兄ならびに被験者各位に深く感謝いたします。

本論文の要旨は, 第 101 回日本補緅歯科学会学術大会 (1999 年 5 月 20 日, 福岡), 第 21 回日本靧口腔機能学会学術大会 （2000 年 4 月 22 日，東京）において発表した。

\section{文献}

1）川添堯涁，田中昌博，井田治彦ほか，新しい咬合診査機 器 T-Scanシステムについて. 歯科医学 $51: 1148$ 1154, 1988

2）鈴木哲也，渡邊竜登美，吉富信幸ほか，感圧シートを用 いた新しい咬合力測定システムの有用性. 補緅誌 38 ： 966-973, 1994.

3）徳村和明，山下 敦。咬合分析装置 T-Scan system に 関する研究．その1。精度について，補緅誌 $33 ： 1037-$ 1043, 1989

4）岡島 努。咀緭筋筋電図による咬合力測定に関する基礎 的研究. 鶴見歯学 $12: 367-390,1986$.

5）石川佳和． 全部床義蒾装着者の咀嚼筋筋電図による咬合 力測定に関する研究. 鶴見歯学 $16: 29-49,1990$.

6）平田博昭. 筋電図による咬合力測定法における咬みしめ 速度の影響に関する研究. 鶴見歯学 $15 ： 211-233,1989$.
7）桝尾隆一，咀罚筋筋電図による全部床義歯機能時の咬合 力算出法. 補綴誌 $36: 893-907,1992$.

8）野本種邦，富田汪助．咬合力と咀罚筋筋電図との関係 （第 1 報）棘波数計測・電位累積装置による研究. 補緅 誌 $19: 641-646,1976$

9) Hosoi $T$, Ishikawa $Y$, Okajima $T$ et al. An evaluation of denture wearers using the biting force and pressure distribution measurement system. Dentistry in Japan $29: 59-64,1992$.

10) Wical KE, Swoop CC. Study of residual ridge resorption. Part I Use of panoramic radiographs for evaluation and classification of mandibular resorption. $\mathrm{J}$ Prosthet Dent 32:7-12, 1974.

11）椎名順朗, 細井紀雄. 無歯䅡患者の回転パノラマ $\mathrm{X}$ 線撮 影による下顎骨の観察. 鶴見歯学 $16: 281-287,1990$.

12）船越正也. 老年者の口腔の生理的変化. 歯科ジャーナル $10: 427-434,1979$

13）山田好秋. 筋の疲労および疼痛. 石岡 靖, 小林義典, 長谷川成男ほか編，䫟口腔機能分析の基礎とその応用 188-197, 東京：デンタルダイヤモンド社, 1991.

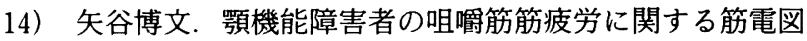
学的研究. 広大歯誌 $17: 170-194,1985$.

15）遠藤憲史．総義歯における咬合高径の相違による咀嚼力 および咬合力に関する研究 第 1 報 第 1 大兒歯部につ いて。補緅誌 $20 ： 755-772,1976$.

16）高橋宏嘉. 義歯床下粘膜の局所負担圧分布に関する実験 的研究. 鶴見歯学 $9: 49-72,1983$.

17）大貫昌理. 下顎義歯床下粘膜の局所負担圧分布に関する 研究. 鶴見歯学 $12: 35-67,1986$.

18）米山喜一. 咬合力の床下支持組織への伝達に関する基礎 的研究. 鶴見歯学 $16: 173-195,1990$.

19）沖倉喜彰、下顎全部床義歯の咬合調整と負担圧分布に関 する研究. 補綴誌 $34 ： 1247-1259,1990$.

20）西村克彦. 咬合接触と義歯床下粘膜の負担圧分布に関す る基礎的研究. 鶴見歯学 17：101-118, 1991.

21）吉野由紀子．咬合高径の増減が下䫇義歯床下粘膜の局所 負担圧分布に及ほす影響. 鶴見歯学 $25 ： 63-77,1999$.

22）作間靖信. 下顎全部床義歯床下粘膜の局所負担圧分布に 関する実験的研究. 鶴見歯学 $14: 47-110,1988$.

23）寒河江 孝. 全部床義歯装着者の咀絪筋筋電図と咬合力 に関する統計学的解析. 鶴見歯学 $18: 1-12,1992$.

24) Helkimo E, Carlsson GE, Helkimo M. Chewing efficiency and state of dentition. Acta Odontol Scand $36: 33-41,1978$.

著者連絡先：川崎 輝

干230-8501 神奈川県横浜市鶴見区鶴見 $2-1-3$

TEL : 045-581-1001 


\title{
A Study on Simplification of the Calculations of the Biting Forces Using Integrated Electromyogram in Complete Denture Wearers
}

\author{
Teru Kawasaki
}

The First Department of Prosthetic Dentistry, Tsurumi University School of Dental Medicine (Director: Prof. Toshio Hosoi)

J Jpn Prosthodont Soc $45: 32-41,2001$

\section{ABSTRACT}

Purpose : The purpose of this study was to decrease the burden in both patients and clinicians, and to improve measurement accuracy, in a system to calculate biting forces during clenching from electromyograms of masticatory muscles.

Methods : We first calculated a representative regression formula in all the subjects, and a regression formula of respective integrated electromyograms (I-EMG), and evaluated the error of the calculated values of biting forces. We also attempted to simplify the calculation method. Then, we evaluated the correlation between the coefficient $(\beta)$ in the regression formula and various related factors, such as the area of the lower denture base, to determine the factors that were related to the coefficient $(\beta)$ in the regression formula.

Results : The error of the values of biting forces that were calculated from the representative formula in all the subjects, was $32 \%$ compared with the actually measured values. Regarding the representative formula of respective I-EMGs, it was shown that the error of the calculated values of biting forces was less than $19 \%$ in the subjects with maximum values of I-EMG of less than $6.0 \mu \mathrm{V} \cdot \mathrm{s}$, and less than $25 \%$ in the subjects with maximum values of I-EMG of more than $6.0 \mu \mathrm{V} \cdot \mathrm{s}$. The correlation with the coefficient $(\beta)$ was higher in the order of the buccolingual cross-sectional area of the alveolar ridge in the lower posterior tooth region, the maximum value of I-EMG, the buccolingual width of the alveolar ridge in the lower posterior tooth area, the area of lower jaw denture base, the age of the subject, and mandibular corpus height.

Conclusions : These results suggested that it was necessary to determine the representative formula by classifying the subjects based on the related factors to the coefficient $(\beta)$ in the regression formula.

\section{Key words}

complete denture, function assessment, biting force, integrated electromyogram 